\title{
Optimising processing conditions for the functionalisation of photocatalytic glazes by $\mathrm{ZnO}$ nanoparticle deposition
}

\author{
๑H.R. Guzmán-Carrillo ${ }^{\mathrm{a}}$ ๑E. Jiménez-Relinque ${ }^{\mathrm{b}} \bowtie$, $₫ \mathrm{~A}$. Manzano-Ramírez ${ }^{\mathrm{a}}, \oplus \mathrm{M}$. Castellote ${ }^{\mathrm{b}}, \oplus \mathrm{M}$. \\ Romero-Pérez ${ }^{\mathrm{c}}$ \\ a. CINVESTAV-I.P.N, Unidad Querétaro, (Querétaro, México). \\ b. Group of Sustainable Interaction of Materials with the Environment (ISCMA-IETcc), Eduardo Torroja Institute for Construction \\ Sciences (IETcc-CSIC), (Madrid, Spain). \\ c. Group of Materials and Energy for a Sustainable Development (MEDES-IETcc), Eduardo Torroja Institute for Construction Sciences \\ (IETcc-CSIC), (Madrid, Spain). \\ eva.jimenez@csic.es
}

Received 15 March 2021

Accepted 22 August 2021

Available on line 24 September 2021

\begin{abstract}
ZnO nanospheres were synthesised and then deposited by both single- and double-fire fast processes on as-prepared ceramic substrates. The photocatalytic degradation of resazurin ink was tested under UV light. The single-fired samples did not show any evidence of photocatalytic activity because the nanoparticles melted during sintering at $1210^{\circ} \mathrm{C}$. The double-fire $\mathrm{ZnO}$ spray-coating method successfully produced glazed materials with an active $\mathrm{ZnO}$ surface layer despite the high sintering temperature. The influence of experimental parameters, including the $\mathrm{ZnO}$ nanoparticle loading $\left(0.03\right.$ to $\left.1 \mathrm{mg} / \mathrm{cm}^{2}\right)$ and firing temperature $\left(650\right.$ to $\left.800^{\circ} \mathrm{C}\right)$, were also investigated. Samples with a $\mathrm{ZnO}$ loading of $1 \mathrm{~g} / \mathrm{cm}^{2}$ fired at $650^{\circ} \mathrm{C}$ showed the best photocatalytic activity. Increasing the temperature to 700 and $800^{\circ} \mathrm{C}$ led to the coalescence of $\mathrm{ZnO}$ nanoparticles, which reduced the photocatalytic activity.
\end{abstract}

KEYWORDS: ZnO; Nanospheres; Photocatalysis; Ceramic tiles; Operation conditions.

Citation/Citar como: Guzmán-Carrillo, H.R.; Jiménez-Relinque, E.; Manzano-Ramírez, M.; Castellote, M.; Romero-Pérez, M. (2021) Optimising processing conditions for the functionalisation of photocatalytic glazes by $\mathrm{ZnO}$ nanoparticle deposition. Mater. Construcc. 71 [344], e261. https://doi.org/10.3989/mc.2021.04921.

RESUMEN: Optimización de las condiciones de procesamiento para la funcionalización de materiales vidriados fotocatalíticos mediante la deposición de nanopartículas de $\mathrm{ZnO}$. Nanoesferas de $\mathrm{ZnO}$ se sintetizaron y se depositaron mediante procesos "singleand double-fire fast" sobre sustratos cerámicos. La degradación fotocatalítica de la tinta de resazurina se probó bajo luz ultravioleta. Las muestras de "single-fire" no mostraron ninguna evidencia de actividad fotocatalítica porque las nanopartículas se derritieron durante la sinterización a $1210^{\circ} \mathrm{C}$. El método de recubrimiento por pulverización de $\mathrm{ZnO}$ de "double-fire" produjo con éxito materiales vidriados con una capa superficial de $\mathrm{ZnO}$ activo a pesar de la elecada temperatura de sinterización. La influencia de los parámetros experimentales, incluida la carga de nanopartículas de $\mathrm{ZnO}$ y la temperatura de cocción también fue analizada. Las muestras con una carga de $\mathrm{ZnO}$ de $1 \mathrm{~g} / \mathrm{cm}^{2}$ cocidas a $650^{\circ} \mathrm{C}$ mostraron la mejor actividad fotocatalítica. El aumento de la temperatura de 700 y $800^{\circ} \mathrm{C}$ condujo a la coalescencia de nanopartículas de $\mathrm{ZnO}$, lo que redujo la actividad fotocatalítica.

PALABRAS CLAVE: ZnO; Nanosferas; Fotocatálisis; Azulejos de cerámica; Condiciones de operación.

Copyright: (C2021 CSIC. This is an open-access article distributed under the terms of the Creative Commons Attribution 4.0 International (CC BY 4.0) License. 


\section{INTRODUCTION}

Ceramics are extensively used as materials for both outdoor and indoor building and construction (i.e. flooring, wall coverings, roofing, ventilated facades, insulating panelling, tunnel lining, and sanitary ware). In 2019 , the world production of ceramic tiles was 12,673 million square meters (data reported by the Association of Italian Manufacturers of Machinery and Equipment for the Ceramic Industry, ACIMAC).

The unique properties of ceramics (enhanced energy efficiency and thermal comfort, resilience to corrosion, and versatility) ensure that ceramics will continue to play a fundamental role in the construction and housing sectors. The industry has developed a strategy of ongoing innovation to aggregate value in the final product; high-definition decoration and low-thickness products have opened the market for functional tiles that go beyond traditional applications $(1,2)$. Recently, efforts to produce photocatalytic ceramic tiles, obtained by embedded fine $\mathrm{TiO}_{2}$ particles or coatings, have intensified. Such functionalisation provides materials with de-polluting $(3,4)$, antifogging $(5,6)$, disinfecting (7-9), and self-cleaning capabilities $(10,11)$. Photocatalysis is a light-induced catalytic process for the reduction of organic and inorganic molecules adsorbed on the surface of a semiconductor through redox reactions (12-14).

Meseguer et al. (15) demonstrated the photocatalytic capacity of ceramic glazes as a new functionality of ceramic tiles with applications in construction (such as flooring and wall covering) and in the field (such as air purification and water cleaning). Photocatalytic ceramic tiles are typically prepared by coating the ceramic tile with anatase $\mathrm{TiO}_{2}$ using various deposition techniques, such as spray deposition (16-19), screen printing $(20,21)$ and sol-gel methods (22-24). However, several critical aspects must be considered to obtain suitable $\mathrm{TiO}_{2}$-containing ceramic materials: firing temperature and adhesion of the $\mathrm{TiO}_{2}$ film/particles to the substrate $(21,25,26)$. Temperatures below $\sim 600^{\circ} \mathrm{C}$ do not generate suitable adhesion between the printed $\mathrm{TiO}_{2}$ layer and the ceramic support, but over $\sim 900^{\circ} \mathrm{C}$, there is evidence of a reaction between the $\mathrm{TiO}_{2}$ layer and the glazed support. In addition, the anatase crystal form is transformed into rutile, which might have a detrimental effect on the catalytic behaviour. This effect is more pronounced when thinner $\mathrm{TiO}_{2}$ layers are used (21). Kaho et al. (25) prepared anatase-based glass-ceramic glazes from a frit containing $\mathrm{TiO}_{2}$. The glazed tiles were prepared by firing at $1180^{\circ} \mathrm{C}$ followed by annealing between 600 and $800^{\circ} \mathrm{C}$. However, there was evidence that high temperatures caused a reaction between the $\mathrm{TiO}_{2}$ and the glazed support. The anatase polymorph remained, but it was immersed in the glaze, resulting in non-active photocatalytic materials. Brunel et al. (26) developed anatase glazes by adding $\mathrm{TiO}_{2}$ to commercial frits. The glazed ceramic tiles were fired at $850-1000^{\circ} \mathrm{C}$, but none of the glazes showed notable photocatalytic activity owing to the anatase phase trans- formation. To overcome these shortcomings, $\mathrm{TiO}_{2}$ can be doped with various elements to increase the thermal stability. Thus, photocatalytic ceramic tiles have been prepared by the deposition of $\mathrm{Ni}-\mathrm{TiO}_{2}(27), \mathrm{W}-\mathrm{TiO}_{2}$ (28), $\mathrm{Nb}_{2} \mathrm{O}_{5}-\mathrm{TiO}_{2}(29,30), \mathrm{Ag}-\mathrm{TiO}_{2}(31)$, and ( $\mathrm{Si}, \mathrm{P}$, $\mathrm{Zr})-\mathrm{TiO}_{2}(32)$. In addition, the adhesion constraint can also be controlled by silanising $\mathrm{TiO}_{2}$ particles before depositing $\mathrm{TiO}_{2}-\mathrm{SiO}_{2}$ coatings (33-36).

A number of photocatalysts, including $\mathrm{ZnO}$, have been investigated as alternatives to $\mathrm{TiO}_{2}$. $\mathrm{ZnO}$ exhibits similar or greater (37-40) photocatalytic performance for degrading pollutants compared to that of $\mathrm{TiO}_{2}$ because of its higher electron mobility and valence band oxidation potential. In addition, $\mathrm{ZnO}$ does not pose risks to human health or the environment (41), and it is cheaper than $\mathrm{TiO}_{2}$. Therefore, $\mathrm{ZnO}$ may be more suitable for large-scale applications in the ceramic industry (42-44). However, few studies have been conducted on the development of $\mathrm{ZnO}$-containing photocatalytic ceramic tiles with applications in construction. In Rego et al.(20) and Marto et al. (45), fabricated screen-printed $\mathrm{ZnO}$ layer on ceramic tiles, and the tiles demonstrated comparable Orange II decolourisation performance to that of aqueous $\mathrm{ZnO}$ suspensions under different artificial light conditions and direct exposure to sunlight, with the advantage of avoiding the removal of the photocatalyst from the liquid media at the end of the process. However, $\mathrm{TiO}_{2}$ layers showed superior performance compared to that of $\mathrm{ZnO}$ (20). Singh et al. (46) demonstrated that $\mathrm{ZnO}$-crystallised glasses have good antibacterial properties against Escherichia coli. $\mathrm{ZnO}$ catalysts doped with $\mathrm{Fe}$ (47), $\mathrm{La}$ (48) and $\mathrm{Cu}$ (49) were deposited on ceramic surfaces to evaluate the photocatalytic performance for dye degradation under visible light. The photocatalytic activity of these coupled photocatalysts was higher than that of a single photocatalyst.

However, the influence of processing conditions during the functionalisation of photocatalytic glazes by $\mathrm{ZnO}$ nanoparticle deposition on the microstructure and the consequent photocatalytic efficiency have not been studied in detail. Therefore, in this work, ceramic tiles were coated with a $\mathrm{ZnO}$ active layer by the conventional fast-firing route used to manufacture construction ceramic tiles. As-prepared $\mathrm{ZnO}$ nanospheres were deposited by both single- and double-fire fast processes. The influence of the firing temperature $\left(650-800^{\circ} \mathrm{C}\right)$ and deposited $\mathrm{ZnO}$ concentration $\left(0.03-1 \mathrm{mg} / \mathrm{cm}^{2}\right)$ on the physicochemical properties and UV photocatalytic activity of the resulting ceramic glazes were evaluated.

\section{MATERIALS AND METHODS}

\subsection{Ceramic substrate preparation}

Green ceramic substrates were prepared according to a previously reported method (50). A spray-dried 
powder for porcelain stoneware tile manufacturing was used, which consisted of a mixture of milled kaolinitic clays, quartz, and feldspars. Wetted powder $(30 \mathrm{~g}, 6 \mathrm{wt} . \%)$ was uniaxially pressed $(40 \mathrm{~mm} \times 50$ $\mathrm{mm} \times 10 \mathrm{~mm})$ at a pressure of $40 \mathrm{MPa}$ in a steel mould. Green substrates were dried at $100^{\circ} \mathrm{C}$ for $24 \mathrm{~h}$ and kept in a desiccator until they were coated with a glaze layer.

\subsection{Preparation and deposition of $\mathrm{ZnO}$ nanoparticles}

$\mathrm{ZnO}$ nanospheres were prepared by a modified polyol method, as described in detail elsewhere (51). Briefly, 2.196 g of non-dehydrated zinc acetate was dissolved in $10 \mathrm{~mL}$ of ethylene glycol by refluxing in a three-necked flask under vigorous stirring. After $30 \mathrm{~min}$, deionised water was injected with a fixed hydration ratio of 8 , and the solution was heated at $160^{\circ} \mathrm{C}$ for $5 \mathrm{~h}$. After successive stages of cooling, centrifugation, and washing, the $\mathrm{ZnO}$ nanospheres were dried in a conventional oven at $80^{\circ} \mathrm{C}$. The $\mathrm{ZnO}$ nanoparticles were deposited on the ceramic substrate using both single- and double-fire processes. In the single-fire process, $\mathrm{ZnO}$ nanospheres (10.0 wt.\%, $38 \mathrm{~nm}$ particle size) were mixed with a commercial frit and poured on the green porcelain stoneware (Figure 1a). In the double-fire process, a glaze slip was first poured onto the surface of the green porcelain stoneware bodies, as shown in Figure $1 \mathrm{~b}$. Then, $10 \mathrm{~g}$ of $\mathrm{ZnO}$ nanospheres were suspended in ethanol (1:1 wt.\%) and stirred for $45 \mathrm{~min}$ at room temperature. Five active layers of $\mathrm{ZnO}$ nanoparticles were then deposited on the glazed porcelain stoneware by a spraying technique using an aerosol spray gun at $0.6 \mathrm{MPa}$ with $15 \mathrm{~cm}$ between the gun and the samples. Four different $\mathrm{ZnO}$ concentrations $(0.03$, $0.1,0.5$, and $1 \mathrm{mg} / \mathrm{cm}^{2}$ ) were deposited, which were dried at $80^{\circ} \mathrm{C}$ for $5 \mathrm{~min}$ and then fired at $650^{\circ} \mathrm{C}$ for $10 \mathrm{~min}$. In addition, $1 \mathrm{mg} / \mathrm{cm}^{2}$ of $\mathrm{ZnO}$ nanospheres was deposited on multiple samples, which were fired at 700 and $800^{\circ} \mathrm{C}$ for $10 \mathrm{~min}$ to evaluate the effect of temperature.

In both the single- and double-fire processes, the glaze slip consisted of a mixture of a commercial frit for a glossy-finish glaze (90.0 wt.\%), carboxy methyl cellulose (5.0 wt.\%), and sodium polymetaphosphate $(5.0 \mathrm{wt} . \%)$ combined with distilled water at a liquid-to-solid ratio of 70:30.

To avoid interference in the subsequent analysis of the $\mathrm{ZnO}$ nanoparticle layers, a $\mathrm{ZnO}$-free frit was also applied. After drying, the glazed bodies resulting from both processes were sintered in a conventional kiln at $1210^{\circ} \mathrm{C}$, followed by a fast-firing process.

\subsection{Physicochemical characterisation}

The commercial frit was previously characterised by X-ray fluorescence (XRF) (Bruker model S8 Tiger), and its thermal behaviour was determined by differential scanning calorimetry (DSC) using a Setaram (Labsys) thermogravimetric-differential thermal analysis (TG-DTA)/DSC unit in air at a heating rate of $10^{\circ} \mathrm{C} / \mathrm{min}$. The crystalline phases of the glazed ceramic samples were characterised by X-ray powder diffraction (XRD) using a Bruker D8 Advance diffractometer with $\mathrm{Cu} \mathrm{K} \alpha$ radiation (40 $\mathrm{kV}, 30 \mathrm{~mA}$ ). The microstructure of the $\mathrm{ZnO}$ layers was analysed by field-emission scanning electron microscopy (FE-SEM) (Hitachi model S-4800) and energy-dispersive spectroscopy (EDX) (detector: Bruker AXS, software: Quantax Esprit 1.9). FESEM observations were performed on the surfaces of the tiles. The samples were coated with a thin $\mathrm{Au}-$ Pd layer to facilitate observation.

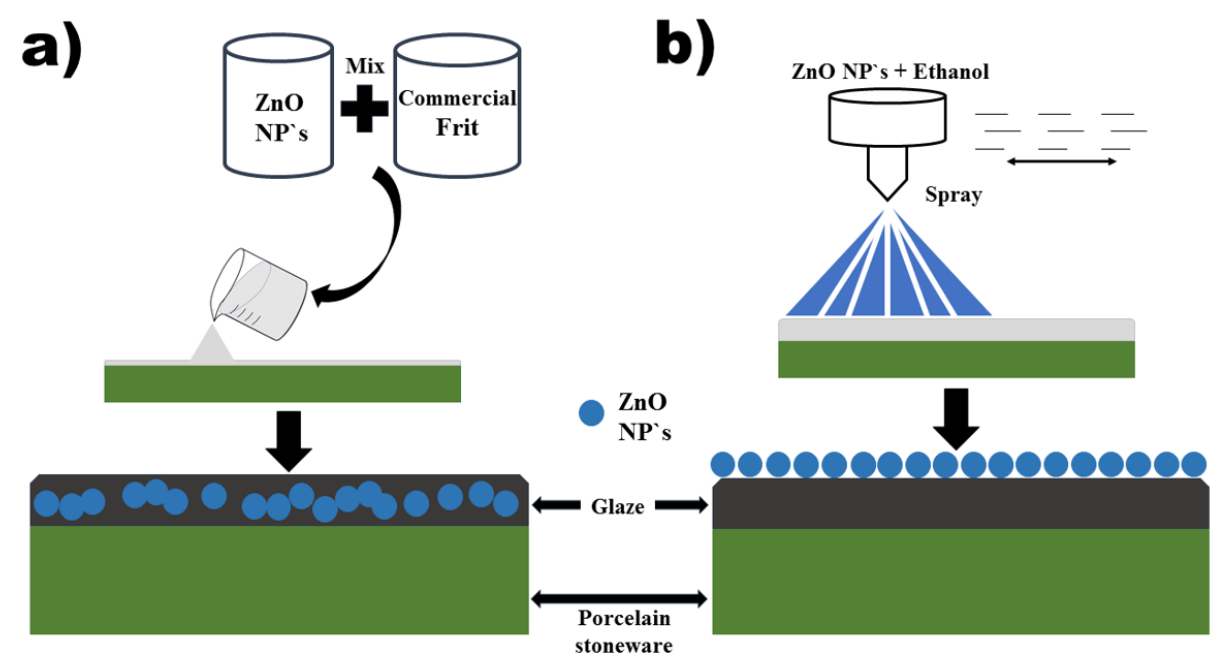

Figure 1. Deposition of ZnO nanoparticles (NPs) on the substrate by the (a) single-fire and (b) double-fire processes. 


\subsection{Photocatalytic activity measurement}

The photocatalytic activity of the as-prepared samples was assessed using resazurin (Rz) 'intelligent ink'. The photocatalytic activity indicator ink comprised a dye (Rz), a sacrificial electron donor (SED, glycerol), and a polymer (hydroxyethyl cellulose, HEC) to encapsulate the dye and SED after the ink dried. The effectiveness of the Rz dye as a photocatalytic activity indicator ink has been previously demonstrated for a wide range of photocatalytic samples $(12,39,52-55)$. It can simply, rapidly, and cheaply probe the photocatalytic activity. Upon irradiation (hv $\geq$ band gap energy) of the ink-coated photocatalytic surface, the photogenerated electrons reduce the blue $\mathrm{Rz}(608 \mathrm{~nm})$ to the pink resorufin (Rf, $588 \mathrm{~nm}$ ) (Figure 2). Rf can be subsequently reduced to its colourless counterpart, dihydroresorufin (HRf). Simultaneously, the photogenerated holes oxidise the glycerol into glyceric acid, which acts as a hole trap to prevent electron-hole recombination. The colour/absorbance change during irradiation provides proof of the photocatalytic activity of the tested material.

The ink formulation used in this study consisted of a redox dye (Rz, $10 \mathrm{mg}$ ), SED (glycerol, $0.8 \mathrm{~g}$ ), and polymer (HEC, $1.1 \mathrm{~g})$ dissolved in ethanol (12 $\mathrm{mL}$ ). The dissolvents were modified with respect to the typical formulation in water to avoid the hydrophobic effect of the ZnO-coated samples and thus obtain a homogeneous Rz ink layer. The glazed samples were coated with the $\mathrm{Rz}$ ink using a wire-wound rod with a pitch that was $750 \mu \mathrm{m}$ long and $350 \mu \mathrm{m}$ in diameter. A typical dried ink film was approximately $20 \mu \mathrm{m}$ thick (measured by SEM analysis). The irradiation of ink-coated samples was conducted using two UV fluorescence tubes (Philips TL-D $15 \mathrm{~W}$ Actinic BL) with $\lambda_{\text {max }}$ emission of $368 \mathrm{~nm}$. The samples were irradiated with a UV-A irradiance of $8.6 \mathrm{~mW} / \mathrm{cm}^{2}$.

The changes in the UV-Vis spectra of the ink-coated films were recorded at different irradiation time intervals using a 2600 Shimadzu UV-Vis

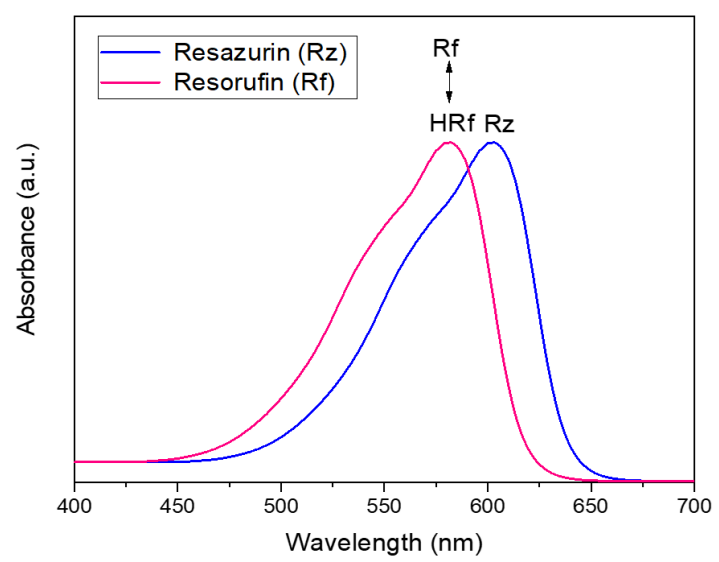

FIGURE 2. Resazurin and resorufin UV-Vis absorbance spectra. spectrophotometer equipped with an integrated reflectance sphere. Simultaneously, digital images of the ink-coated glazed samples were recorded using a digital camera (Bridge Sony Cyber-Shot, 20.1 MP). The images were imported into the digital processing software ImageJ $1.52 \mathrm{n} \mathrm{Fiji,} \mathrm{and} \mathrm{the} \mathrm{average} \mathrm{RGB}$ (red, blue, and green) pixel intensities were collected from the images. Then, the normalised red and blue components, $n R t$ and $n B t$, respectively, at time $t$ of irradiation were calculated using Equations [1] and [2]. This type of analysis has been successfully performed in previous studies $(56,57)$.

$$
\begin{aligned}
& n R t=\frac{R t}{R t+G t+B t} \\
& n B t=\frac{B t}{R t+G t+B t}
\end{aligned}
$$

\section{RESULTS AND DISCUSSION}

\subsection{Characterisation of the glass frit}

Table 1 lists the chemical composition of the commercial frit used to prepare the glaze. It is a common silica-sodic material and was selected for this study because it does not contain $\mathrm{ZnO}$. The $\mathrm{TG}-$ DTA curves of the glass frit are shown in Figure 3. The first endothermic peak occurred at $110^{\circ} \mathrm{C}$, corresponding to the release of water adsorbed on the surface of the commercial frit particles. A second intense endothermic effect occurred at $540-700^{\circ} \mathrm{C}$, which is related to the formation of liquid phases; in particular, the glass frit melted at $605^{\circ} \mathrm{C}$. These features are relevant for the optimum processing conditions, as discussed later.

\subsection{Single-fire process}

The SEM image of the $\mathrm{ZnO}$ nanoparticles shown in Figure $4 \mathrm{a}$ shows that the $\mathrm{ZnO}$ nanoparticles had an almost spherical morphology and were 30-40 nm in size. Figure $4 \mathrm{~b}$ shows a digital image of the glazed

TABLE 1. XRF chemical composition (wt.\%) of the commercial glass frit.

\begin{tabular}{cccc}
\hline Oxide & Percentage & Oxide & Percentage \\
\hline $\mathrm{SiO}_{2}$ & 69.22 & $\mathrm{SO}_{3}$ & 0.251 \\
$\mathrm{Na}_{2} \mathrm{O}$ & 15.6 & $\mathrm{Fe}_{2} \mathrm{O}_{3}$ & 0.205 \\
$\mathrm{CaO}$ & 9.08 & $\mathrm{Cl}$ & 0.061 \\
$\mathrm{MgO}$ & 4.28 & $\mathrm{TiO}_{2}$ & 0.053 \\
$\mathrm{Al}_{2} \mathrm{O}_{3}$ & 0.914 & $\mathrm{~B}_{2} \mathrm{O}_{3}$ & 0.061 \\
$\mathrm{~K}_{2} \mathrm{O}$ & 0.263 & $\mathrm{ZrO}_{2}$ & 0.012 \\
\hline
\end{tabular}




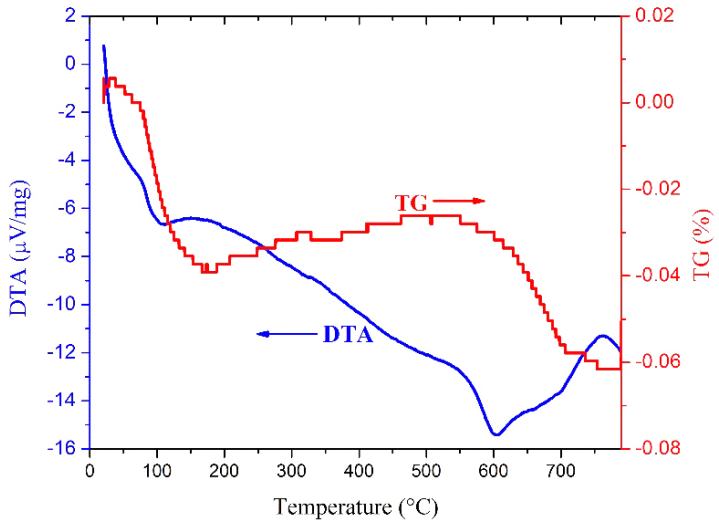

FIGURE 3. TG-DTA results of the commercial frit.

porcelain stoneware tile covered with a layer of $\mathrm{ZnO}$ nanoparticles by the single-fire process. The glaze was transparent with a crackle finish. It should be noted that the surface of the glaze prepared without $\mathrm{ZnO}$ nanoparticles also cracked, and the introduction of the nanoparticles did not noticeably affect the surface appearance of the glazes. The XRD patterns of the single-fired glazed samples with and without $\mathrm{ZnO}$ nanoparticles are shown in Figure 4c. No difference was observed between the two patterns, except for the presence of a small peak assigned to cristobalite $\left(\mathrm{SiO}_{2}\right)$ from commercial frit on the glazed sample without $\mathrm{ZnO}$. No $\mathrm{ZnO}$ crystalline phases were detected in the $\mathrm{ZnO}$-coated glazed sample. However, Figure $4 \mathrm{c}$ shows the diffractogram of a sample of $\mathrm{ZnO}$ nanoparticles subjected to the same thermal cycle with which the tiles were fired. The $\mathrm{ZnO}$ nanoparticles did not undergo any mineralogical transformation during firing, and the diffractogram shows the characteristic peaks of zincite. $\mathrm{ZnO}$ is known as a network modifier or former depending on the composition of the glass (58). The role of glass modifiers in low-alkali silicate glasses has been previously reported (59). Thus, it appears that the $\mathrm{ZnO}$ nanoparticles were incorporated into the glass network, acting as a network modifier and avoiding the devitrification of the single-fired glaze. The patterns show an amorphous halo in the range $2 \theta=16^{\circ}-38^{\circ}$, which is characteristic of non-crystalline materials. The absence of a $\mathrm{ZnO}$ crystalline signal for the glaze surface could be because the $\mathrm{ZnO}$ nanoparticles can act as a glass modifier, as mentioned previously. Upon sintering at $1210^{\circ} \mathrm{C}$, the $\mathrm{ZnO}$ nanoparticles may have melted and diffused to become part of the glassy network. Another possibility is that the $\mathrm{ZnO}$ nanoparticles were embedded in the low-viscosity liquid phase originating from the commercial frit during the sintering of the glazed porcelain stoneware tiles.

Figure 5 shows digital images of the $\mathrm{ZnO}$-containing single-fired glazed samples coated with $\mathrm{Rz}$ ink at different irradiation times. These images demonstrate that the ink on the glaze did not show any significant variation in colour during the test a)

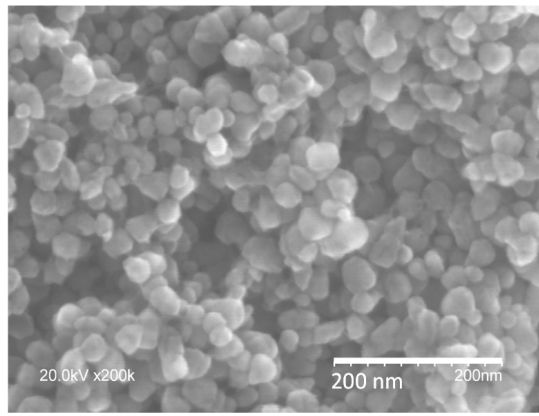

b)

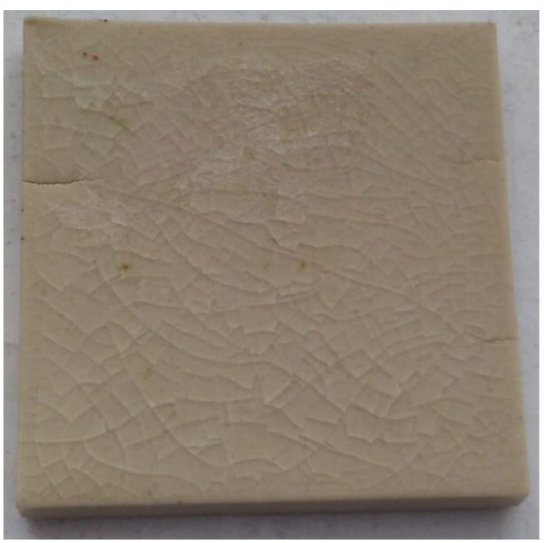

c)

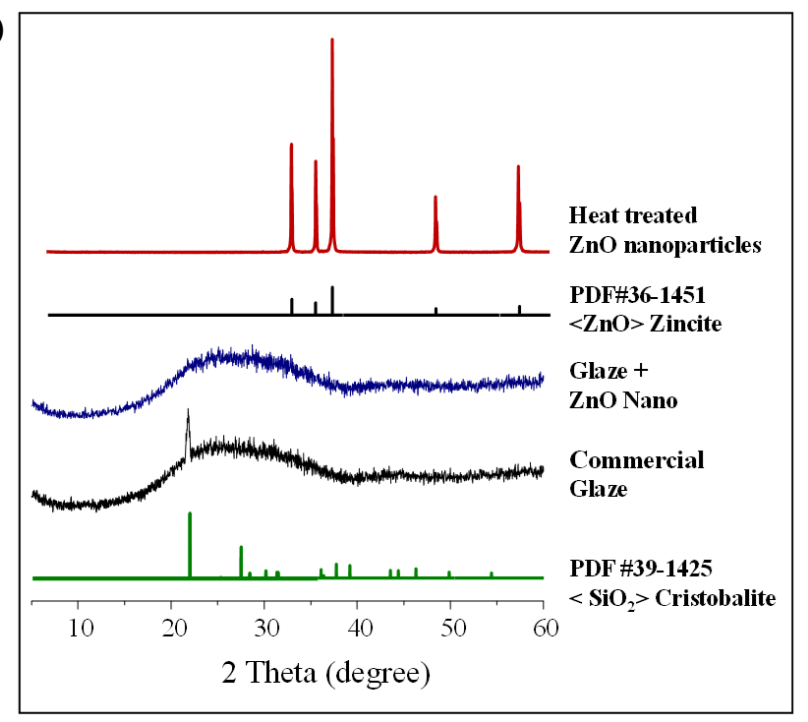

FIGURE 4. (a) SEM image of the $\mathrm{ZnO}$ nanoparticles, (b) digital image of the porcelain stoneware covered with a layer of ZnO nanoparticles by the single-fire process, and (c) XRD patterns of the glazes with and without $\mathrm{ZnO}$ nanoparticles. 


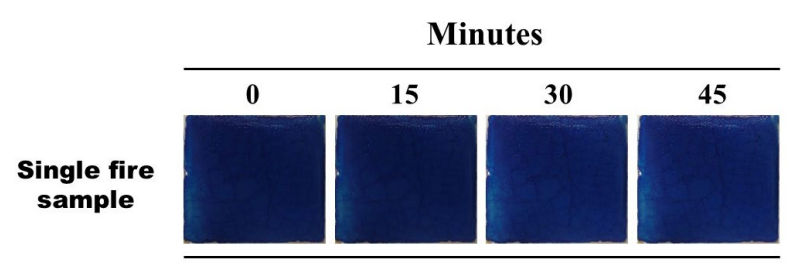

FiguRE 5. Digital images of the Rz-ink-coated glaze containing $\mathrm{ZnO}$ nanoparticles fabricated by the single-fire process at different irradiation times.

irradiation, which proves that the $\mathrm{ZnO}$ nanoparticles incorporated into the glaze did not show any evidence of photocatalytic activity. This finding is consistent with the XRD results discussed previously. All these results indicate the potential difficulties stemming from the complexity of preparing active glazes containing $\mathrm{ZnO}$ nanoparticles by a single-fire process.

\subsection{Double-fire process}

\subsubsection{Effect of the $\mathrm{ZnO}$ concentration}

Figure 6 shows the XRD patterns of the glazes prepared by spraying $\mathrm{ZnO}$ layers on porcelain stoneware tiles following the double-fire procedure $\left(650^{\circ} \mathrm{C}\right.$ for $\left.10 \mathrm{~min}\right)$ using different $\mathrm{ZnO}$ nanoparticles loadings $\left(0.03,0.10,0.50\right.$, and $\left.1.00 \mathrm{mg} / \mathrm{cm}^{2}\right)$

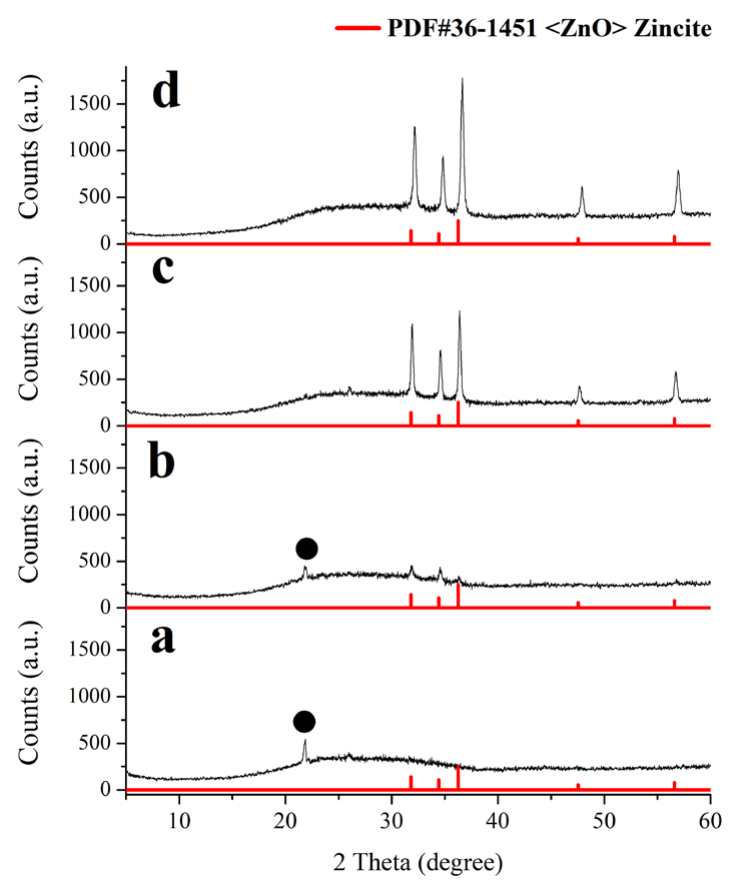

FIGURE 6. XRD patterns of glazed ceramics covered with $\mathrm{ZnO}$ layers of different concentrations prepared by the double-fire process $\left(650^{\circ} \mathrm{C}\right.$ for $10 \mathrm{~min}$ ): (a) $0.03 \mathrm{mg} / \mathrm{cm}^{2}$, (b) $0.10 \mathrm{mg} / \mathrm{cm}^{2}$, (c) $0.50 \mathrm{mg} / \mathrm{cm}^{2}$, and (d) $1.00 \mathrm{mg} / \mathrm{cm}^{2}$. Cristobalite is denoted by $\bullet$.
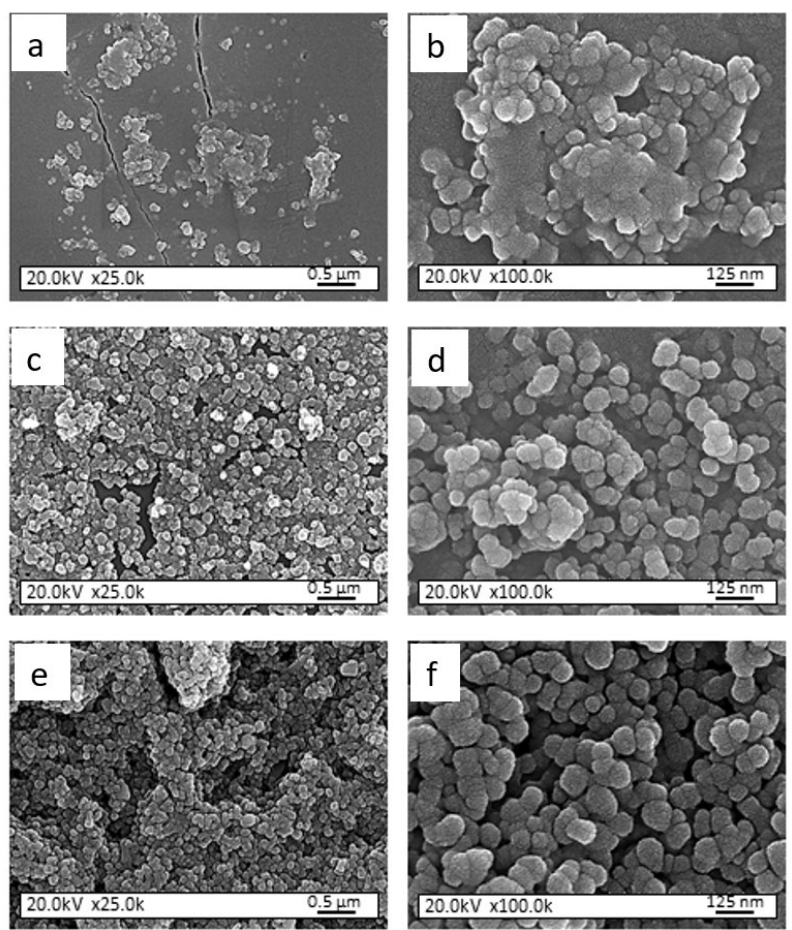

FiguRE 7 . SEM images at $25 \mathrm{k} \times$ and $100 \mathrm{k} \times$ magnifications of the $\mathrm{ZnO}$ glazes prepared by the double-fire process $\left(650^{\circ} \mathrm{C}\right.$ for 10 $\mathrm{min}$ ) with different concentrations of $\mathrm{ZnO}$ nanoparticles: (a-b)

$0.03 \mathrm{mg} / \mathrm{cm}^{2}$, (c-d) $0.10 \mathrm{mg} / \mathrm{cm}^{2}$, and (e-f) $0.50 \mathrm{mg} / \mathrm{cm}^{2}$.

The patterns of the three specimens with the highest concentrations of $\mathrm{ZnO}$ particles $(0.10,0.50$, and 1.00 $\mathrm{mg} / \mathrm{cm}^{2}$ ) confirm the presence of $\mathrm{ZnO}$ nanoparticles on the glaze surface. The working temperature of $650^{\circ} \mathrm{C}$ was in or close to the liquid-phase formation temperature range of the commercial frit. At these temperatures, the viscosity of the liquid phase was insufficient to absorb the nanoparticles, which remained fixed to the surface of the glaze. The peaks correspond to the hexagonal phase of $\mathrm{ZnO}$ (zincite, ICDD-PDF \#36-1451), and no other crystalline phase was detected. The sharp and clear diffraction peaks indicate that the $\mathrm{ZnO}$-glazed samples had a high crystalline quality, as previously reported (51). The intensity of the $\mathrm{ZnO}$ peaks increased as the concentration increased, and no $\mathrm{ZnO}$ peaks were detected at the lowest concentration of nanoparticles $(0.03$ $\mathrm{mg} / \mathrm{cm}^{2}$ ). These results indicate that this double-fire process can be used to obtain glazed tiles with $\mathrm{ZnO}$ nanoparticles on their surfaces. The diffraction patterns also exhibited a peak at $21.9^{\circ}$, which is related to the crystallisation of cristobalite in the glaze from the commercial frit (see Figure 4c).

Figure 7 shows SEM images of the glazed samples fired at $650^{\circ} \mathrm{C}$ for $10 \mathrm{~min}$ using different concentrations of $\mathrm{ZnO}$ nanoparticles. The sample covered with the lowest concentration of $\mathrm{ZnO}$ nanoparticles $\left(0.03 \mathrm{mg} / \mathrm{cm}^{2}\right)$ did not have enough nanoparticles to create a uniform layer, and isolated clusters of nanoparticles were observed on the 
surface of the glaze. Conversely, good substrate coverage was obtained when the concentration of $\mathrm{ZnO}$ nanoparticles increased to between 0.10 and $1.00 \mathrm{mg} / \mathrm{cm}^{2}$. The thickness of the layer was also affected by the $\mathrm{ZnO}$ deposition concentration; the use of a larger concentration created thicker layers. These results are in line with the XRD results described previously.

The size of the $\mathrm{ZnO}$ nanoparticles was measured using Image J image analysis software. Although the particles maintained their nanometric size, the thermal treatment at $650^{\circ} \mathrm{C}$ used to fix the $\mathrm{ZnO}$ layer on the glaze surface resulted in the growth of particles by coalescence, which was more pronounced at higher nanoparticle concentrations. The average size of the $\mathrm{ZnO}$ particles varied from $75 \mathrm{~nm}$ in the glaze prepared with the $0.1 \mathrm{mg} / \mathrm{cm}^{2}$ solution to $100 \mathrm{~nm}$ in the $\mathrm{ZnO}$ layers deposited using the 0.5 and $1.0 \mathrm{mg} /$ $\mathrm{cm}^{2}$ solutions.

The absorbance spectra of the Rz-ink-coated samples fired at $650^{\circ} \mathrm{C}$ with different concentrations of $\mathrm{ZnO}$ nanoparticles at different UV irradiation times and the corresponding digital images of the ink test are shown in Figures $8 \mathrm{a}$ and $8 \mathrm{~b}$, respectively. The colour changes due to the disappearance of $\mathrm{Rz}$ (monitored using the normalised blue component in the RGB system, $n B t$ ) and the concomitant appearance of $\mathrm{Rf}$ (monitored using the normalised red component, $n R t$ ) are illustrated in Figure 8(c). The spectral transition agrees with the digital images. The glaze without $\mathrm{ZnO}$ nanoparticles exhibited no photocatalytic conversion of the $\mathrm{Rz}$ ink. The sample with the lowest nanoparticle concentration $\left(0.03 \mathrm{mg} / \mathrm{cm}^{2}\right)$ showed a slight variation in the original $\mathrm{Rz}$ dye absorbance spectra. The digital images did not exhibit any noticeable changes in colour from blue to pink (Figure $8 \mathrm{~b}$ ), but using the image processing software, a small decrease in $n B t$ and concomitant increase in $n R t$ was detected (Figure $8 \mathrm{c}$ ). Upon increasing the concentration of $\mathrm{ZnO}$ nanoparticles on the surface, an enhanced change in the Rz dye absorbance/colour was observed, which was more visible during the last minutes of UV-A irradiation. The sample with a concentration of 0.10 $\mathrm{mg} / \mathrm{cm}^{2}$ was able to partially transform $\mathrm{Rz}(608 \mathrm{~nm}$, blue) into $\mathrm{Rf}$ (588 nm, pink) but did not reach the a)
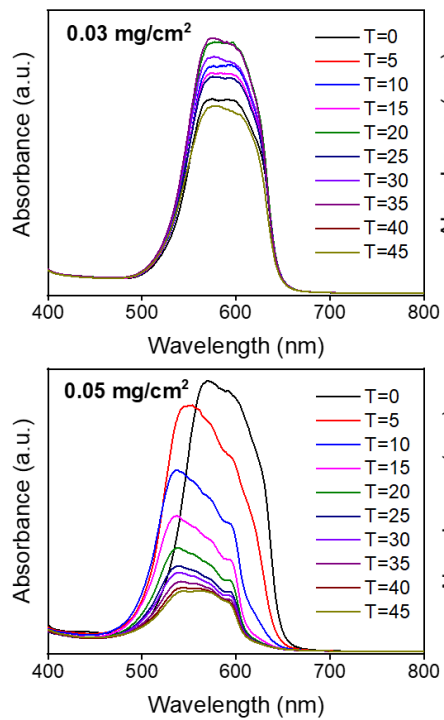
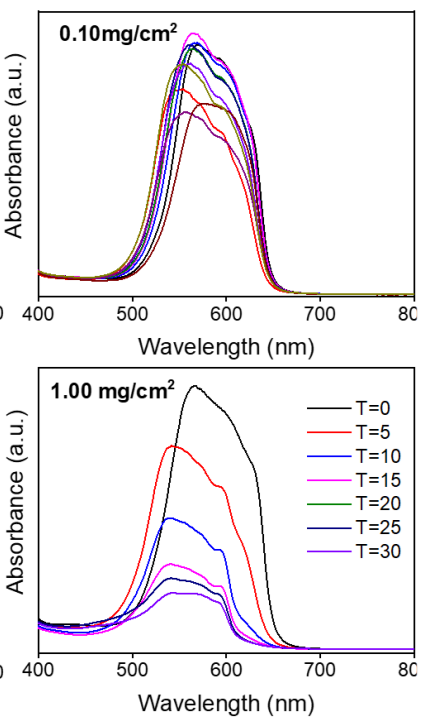

b)

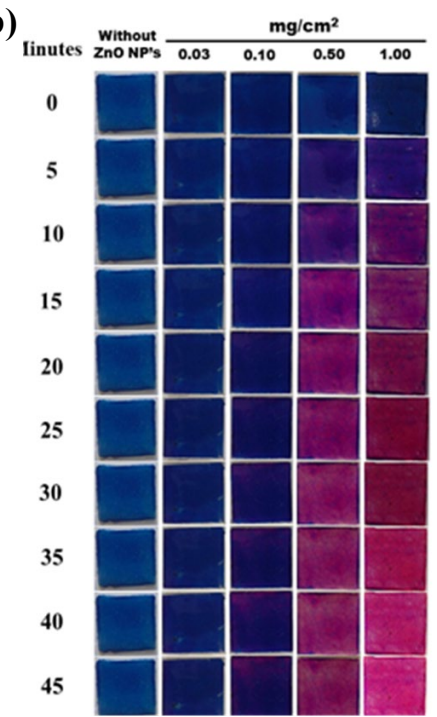

c)
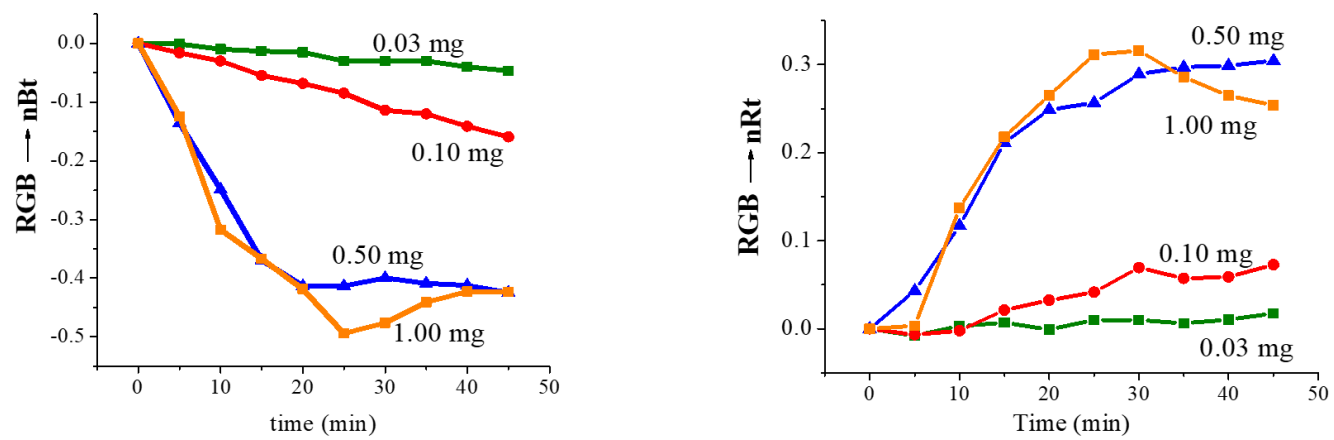

FIGURE 8. (a) Rz ink spectra and (b) digital images at different irradiation times (T, min) of the glazed ceramics tiles prepared by the double-fire process $\left(650^{\circ} \mathrm{C}\right)$ with $\mathrm{ZnO}$ nanoparticle concentrations of $0.03,0.1,0.5$, and $1.0 \mathrm{mg} / \mathrm{cm}^{2}$. (c) Variation in the blue $(n B t)$ and red (nRt) components in the RGB system with irradiation time ( $\mathrm{t}$ ). 
maximum (no plateau state). The colour of the $\mathrm{Rz}$ ink significantly changed as a function of irradiation time in samples with a higher concentration of nanoparticles $\left(0.50\right.$ and $\left.1 \mathrm{mg} / \mathrm{cm}^{2}\right)$, reaching a plateau of maximum red colour (maximum transformation of $\mathrm{Rz}$ to $\mathrm{Rf}$ ) in both cases. The sample coated with $1 \mathrm{mg} / \mathrm{cm}^{2}$ even exhibited a subsequent decrease in blue and red intensity after 25 min of irradiation. This is because the Rz ink compound (blue) entirely transformed into $\mathrm{Rf}$ (pink), and thus the predominant process was bleaching of the ink ( $\mathrm{Rf}$ to HRf (colourless)). The presence of pink colour or even the bleaching of the ink on the surface demonstrated the photocatalytic efficiency of the $\mathrm{ZnO}$-coated glazed stoneware samples prepared by the double-fire route. These findings agree with the XRD and SEM characterisation results discussed previously, all of which indicate that the $\mathrm{ZnO}$ coating created using the lowest concentration of nanoparticles did not create a homogeneous layer, but the higher nanoparticle concentrations allowed the formation of homogeneous $\mathrm{ZnO}$ layers.

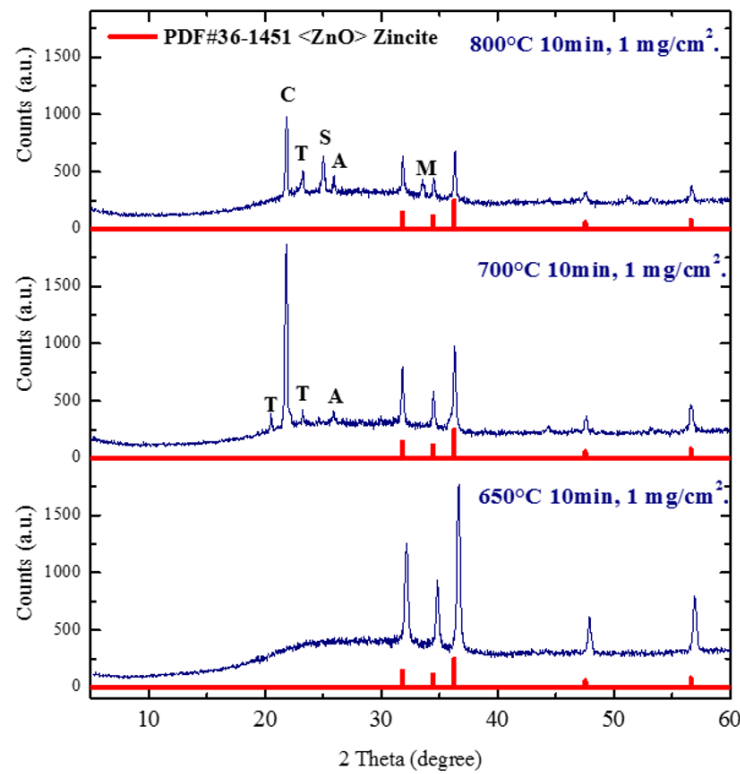

FIGURE 9. XRD patterns of double-fired glazed ceramics covered with a $\mathrm{ZnO}$ layer $\left(1 \mathrm{mg} / \mathrm{cm}^{2}\right)$ and treated at different temperatures. $\mathrm{C}=$ cristobalite, $\mathrm{SiO}_{2} ; \mathrm{M}=$ merwinite, $\mathrm{Zn}_{2}\left(\mathrm{SiO}_{4}\right)$; $\mathrm{T}=$ tridymite, $\mathrm{SiO}_{2} ; \mathrm{S}=$ willemite, $\mathrm{Zn}_{2}\left(\mathrm{SiO}_{4}\right)$; and $\mathrm{A}=$ cordierite, $\mathrm{Mg}_{2} \mathrm{Al}_{4} \mathrm{Si}_{5} \mathrm{O}_{18}$. a)
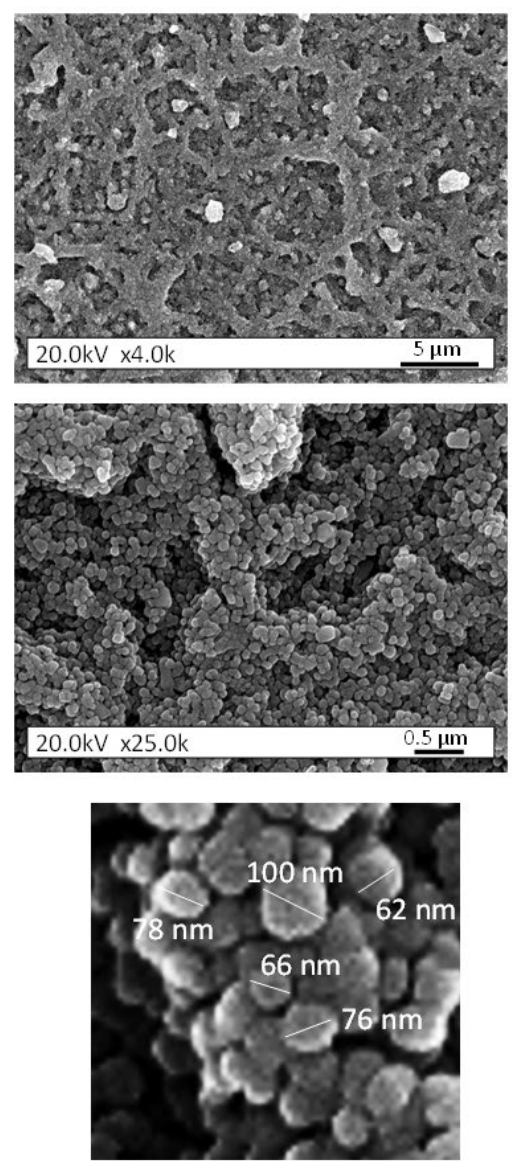

b)
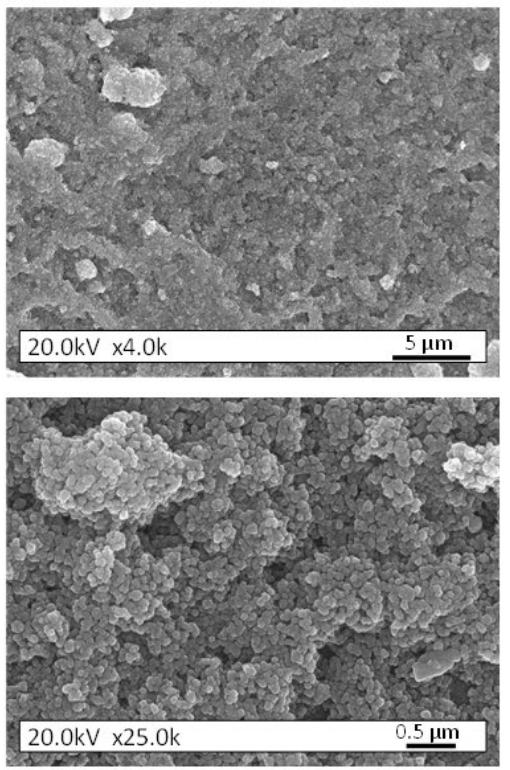

c)
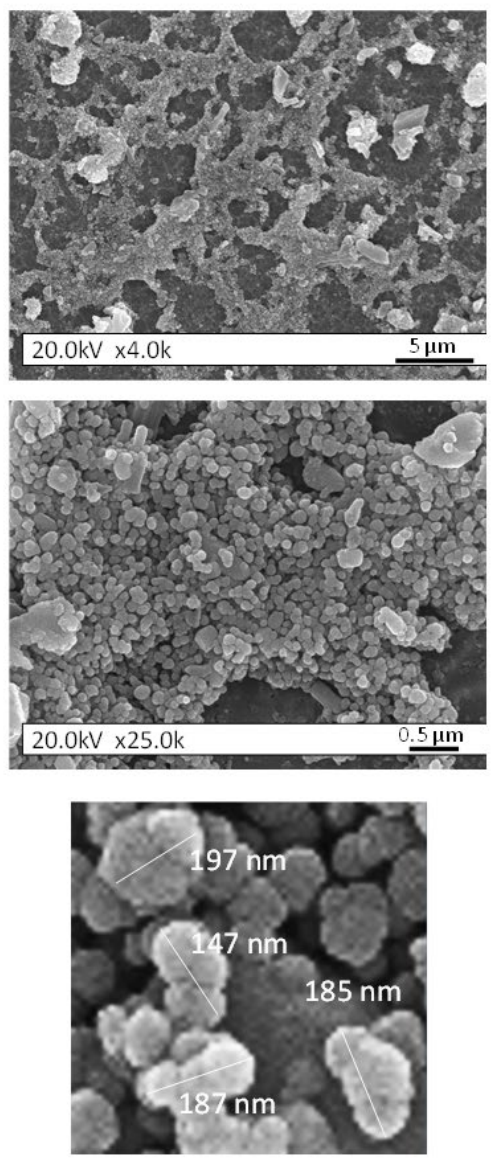

FigURE 10. SEM images at $4 \mathrm{k} \times$ and $25 \mathrm{k} \times$ magnifications of the double-fired glazed tiles thermally treated at (a) $650^{\circ} \mathrm{C}$, (b) $700^{\circ} \mathrm{C}$, and (c) $800^{\circ} \mathrm{C}$ 
a)
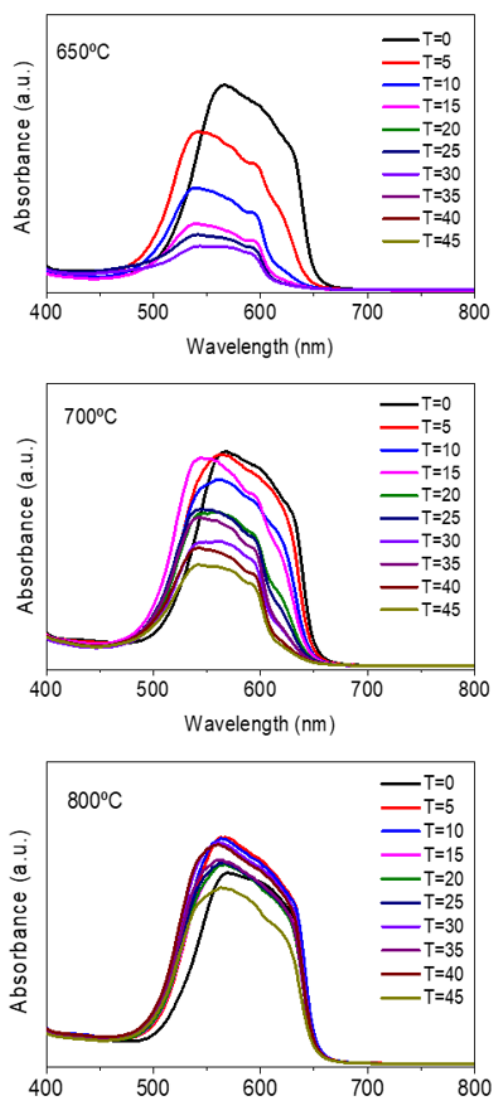

c)

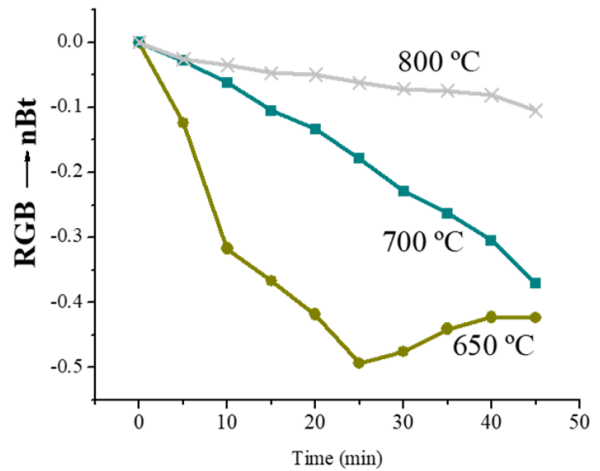

b)
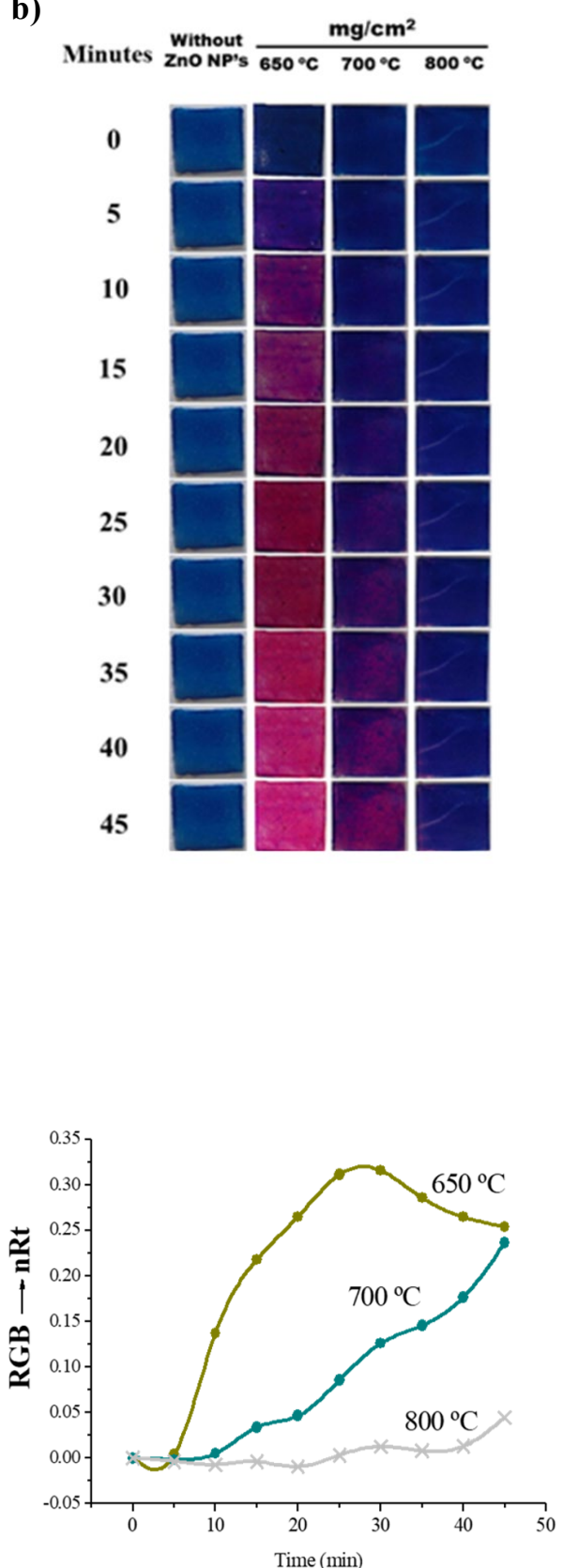

FIGURE 11. (a) Rz ink spectra and (b) digital images at different irradiation times (T, min) of the double-fired glazed ceramics tiles with a $\mathrm{ZnO}$ nanoparticles concentration of $1.0 \mathrm{mg} / \mathrm{cm}^{2}$ thermally treated at 650,700 , and $800^{\circ} \mathrm{C}$. (c) Variation in the red $(n R t)$ and blue $(n B t)$ components in the RGB system with irradiation time $(\mathrm{t})$.

\subsubsection{Effect of the thermal treatment temperature}

The effect of the temperature of the thermal treatment $\left(650,700\right.$, and $\left.800^{\circ} \mathrm{C}\right)$ used to fix the $\mathrm{ZnO}$ nanoparticles was studied on glazed samples covered with a layer of $\mathrm{ZnO}$ nanoparticles at a concentration of $1.00 \mathrm{mg} / \mathrm{cm}^{2}$. Figure 9 shows the XRD patterns of the samples treated at the three different temperatures. The Bragg reflections related to $\mathrm{ZnO}$ decreased as the thermal treatment temperature in- creased. All the samples presented a characteristic broad halo in the range $2 \theta=20^{\circ}-38^{\circ}$ related to the amorphous nature of the glaze. However, the intensity of this halo decreased as the fixing temperature increased owing to the development of new crystalline phases in the glaze. The XRD patterns of the samples treated at 700 and $800^{\circ} \mathrm{C}$ showed peaks related to cristobalite ( $\mathrm{SiO}_{2}$, ICDD-PDF \#39-1425), tridymite $\left(\mathrm{SiO}_{2}, \mathrm{ICDD}-\mathrm{PDF}\right.$ \#42-1401), merwinite $\left(\mathrm{Ca}_{3} \mathrm{Mg}\left(\mathrm{SiO}_{4}\right)_{2}\right.$, ICDD-PDF \#35-0591), cordierite 
( $\mathrm{Mg}_{2} \mathrm{Al}_{4} \mathrm{Si}_{5} \mathrm{O}_{18}$, ICDD-PDF \#14-0249), and willemite $\left(\mathrm{Zn}_{2}\left(\mathrm{SiO}_{4}\right)\right.$, ICDD-PDF \#14-0653). Simultaneously, as the temperature increased, the intensity of the peaks corresponding to zincite decreased considerably. This could be because as the temperature increased, the viscosity of the glaze decreased, and the $\mathrm{ZnO}$ nanoparticles could be embedded in the glaze in a similar manner to that observed in the single-fired glazes. This result was confirmed by the SEM images in Figure 10.

Figure 10 shows SEM images of the glazes subjected to different fixing temperatures. In the sample prepared at $650^{\circ} \mathrm{C}$, a good distribution and continuous layer of $\mathrm{ZnO}$ nanoparticles on the surface was observed, and the original glaze substrate was not detected. Nevertheless, although the final size of the $\mathrm{ZnO}$ nanoparticles increased considerably in the sample fixed at $800^{\circ} \mathrm{C}$ (from $\sim 60-100 \mathrm{~nm}$ to $185-190 \mathrm{~nm}$ ), the layer of nanoparticles on the surface was thinner, allowing the original glaze to show through. The sample treated at $700^{\circ} \mathrm{C}$ exhibited an intermediate appearance; the size of the nanoparticles was larger than that at $650^{\circ} \mathrm{C}$, but the glaze appeared to be fully covered by the layer of nanoparticles.

The absorption spectra of the Rz ink as a function of UV irradiation time on the glazed tiles thermally treated at different temperatures and the corresponding digital images are shown in Figures $11 \mathrm{a}$ and $11 \mathrm{~b}$, respectively. As previously described, the colour change of the Rz ink was monitored using the normalised blue $(n B t)$ and red (nRt) components in the RGB system (Figure 11c). A higher absorbance/colour transformation was observed in the sample treated at $650^{\circ} \mathrm{C}$. Digital image analysis indicated a complete transformation from blue (Rz) to pink (Rf) and subsequent bleaching for the sample treated at $650^{\circ} \mathrm{C}$. As the temperature increased, the $\mathrm{Rz}$ ink reaction was noticeably reduced. The superior photocatalytic performance of the samples treated at $650^{\circ} \mathrm{C}$ is ascribed to the larger quantity of nanoparticles on the surface of the glaze and the minimal nanoparticle growth by coalescence; it is well known that smaller particles have a larger surface area, and the properties of nanoparticles are better in the presence of superficial defects. When the temperature increased, the size of the nanoparticles increased, and the properties were modified. Therefore, the photocatalytic activity was significantly reduced at 700 and $800^{\circ} \mathrm{C}$.

\subsubsection{Kinetic rate analysis}

The apparent rate constant $\left(\mathrm{k}, \mathrm{min}^{-1}\right)$ calculated from the variation in the red colour in the RGB system ( $n R t$ value) versus irradiation time ( $\mathrm{t}$ ) was used to evaluate the impact of the $\mathrm{ZnO}$ loading $\left(\mathrm{mg} / \mathrm{cm}^{2}\right)$ and the fixing temperature on the photocatalytic performance of the samples. The rate constant was calculated for the first reduction step of the reaction, from blue $(\mathrm{Rz})$ to red $(\mathrm{Rf})$, by considering the ink transformation as a first-order reaction (Figure 12). Equation [3] was used to determine the tau value $(\tau)$ from the exponential fit of the $\mathrm{Rz}$ transformation. By applying Equation [4], the kinetic rate (k) of the reaction was obtained. The exponential fit was performed using the first 25 min of irradiation time (first reduction stage of the blue $\mathrm{Rz}$ to pink Rf). The subsequent reduction stage to its colourless counterpart (HRf) was excluded. Table 2 shows the calculated values of tau, the kinetic rate, and $\mathrm{R}^{2}$. The $\mathrm{R}^{2}$ values were higher than 0.9 , which indicates a good fit for the experimental data. A correlation was established between the processing conditions (temperature and concentration) and the calculated reaction rate, as shown in Figure 13. The data indicates that the negative effect of increasing the temperature was severe and proportional to the decrease in the $\mathrm{Rz}$ degradation rate. The $\mathrm{ZnO}$ loading was also a crucial parameter. Three different regions were identified. The first zone had high kinetic rates (samples with concentrations of 0.50 and $1.00 \mathrm{mg} / \mathrm{cm}^{2}$ at $650^{\circ} \mathrm{C}$ ), meaning the materials had high photocatalytic activity. The second zone had intermediate kinetic rates (sample with a concentration of $1.00 \mathrm{mg} / \mathrm{cm}^{2}$ at $700^{\circ} \mathrm{C}$ ), and the third zone had low or negligible kinetic rates (samples with the lowest concentrations, 0.03 and $0.10 \mathrm{mg} /$ $\mathrm{cm}^{2}$, at $650^{\circ} \mathrm{C}$ or with the highest fixing temperature, $800^{\circ} \mathrm{C}$ ), which indicate poor photocatalytic activity.

$$
\begin{gathered}
y=C \cdot e^{\left(-\frac{x}{\tau}\right)} \\
\tau=\frac{1}{k}
\end{gathered}
$$

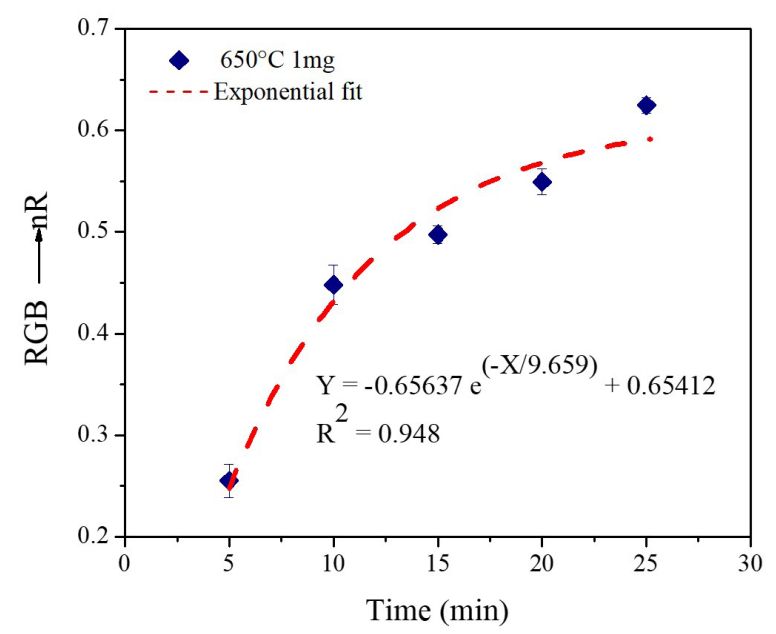

Figure 12. Exponential fit of the photocatalytic kinetic rate of the ceramic tile sample with a $\mathrm{ZnO}$ nanoparticle concentration of $1.0 \mathrm{mg} / \mathrm{cm}^{2}$ thermally treated at $650^{\circ} \mathrm{C}$. 
TABLE 2. Tau values and kinetic (rate) constants calculated for different concentrations of $\mathrm{ZnO}$ nanoparticles and different thermal treatment temperatures.

\begin{tabular}{lccc}
\hline \multirow{2}{*}{ Sample } & \multicolumn{1}{c}{$\tau(\mathrm{RGB})$} & $\mathrm{k}$ & \multirow{2}{*}{$\mathrm{R}^{2}$} \\
\cline { 2 - 3 } & $\mathrm{Red}$ & $\operatorname{Red}\left(\mathrm{min}^{-1}\right)$ & \\
\hline $\begin{array}{l}650^{\circ} \mathrm{C}, 10 \mathrm{~min}, \\
0.03 \mathrm{mg} / \mathrm{cm}^{2}\end{array}$ & 16.003 & 0.06248828 & 0.9067 \\
$\begin{array}{l}650^{\circ} \mathrm{C}, 10 \mathrm{~min}, \\
0.1 \mathrm{mg} / \mathrm{cm}^{2}\end{array}$ & 14.239 & 0.07022965 & 0.9908 \\
$\begin{array}{l}650^{\circ} \mathrm{C}, 10 \mathrm{~min}, \\
0.5 \mathrm{~m} / \mathrm{cm}^{2}\end{array}$ & 11.97 & 0.08354219 & 0.984 \\
$650^{\circ} \mathrm{C}, 10 \mathrm{~min}$, & & & \\
$1 \mathrm{mg} / \mathrm{cm}^{2}$ & 9.659 & 0.10353039 & 0.9486 \\
$700^{\circ} \mathrm{C}, 10 \mathrm{~min}$, & & & \\
$1 \mathrm{mg} / \mathrm{cm}^{2}$ & 12.768 & 0.0783208 & 0.9841 \\
$800^{\circ} \mathrm{C}, 10 \mathrm{~min}$, & & & \\
$1 \mathrm{mg} / \mathrm{cm}^{2}$ & 13.811 & 0.07240605 & 0.9678 \\
\hline
\end{tabular}

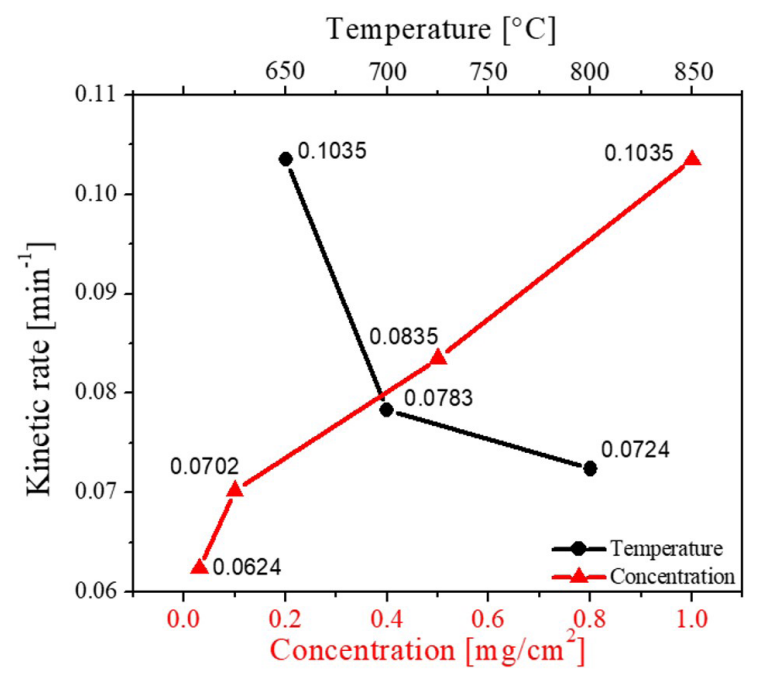

FIGURE 13. Effect of the fixing temperature $\left({ }^{\circ} \mathrm{C}\right)$ and $\mathrm{ZnO}$ nanoparticle concentration $(\mathrm{mg} / \mathrm{cm} 2)$ on the first-order reaction kinetic rate constant $\mathrm{Rz}$ photodegradation reaction on the double-fired glazed materials. Black circles denote samples prepared with a $1 \mathrm{mg} / \mathrm{cm} 2 \mathrm{ZnO}$ nanoparticle concentration at different treatment temperatures, and red triangles denote samples prepared with different $\mathrm{ZnO}$ nanoparticle concentrations at $650^{\circ} \mathrm{C}$.

\section{CONCLUSIONS}

Photocatalytic glazed ceramic tiles were functionalised with $\mathrm{ZnO}$ nanoparticles using two different fast-firing routes. The single-fire process used $\mathrm{ZnO}$ nanospheres ( $10.0 \mathrm{wt} . \%, 30-40 \mathrm{~nm}$ particle size) premixed with a commercial frit, and the resulting tiles did not show any evidence of photocatalytic activity (measured by an $\mathrm{Rz}$ ink test). The $\mathrm{ZnO}$ nanoparticles melted, leaving the surface and becoming part of the glassy network during sintering at $1210^{\circ} \mathrm{C}$.
In the double-fire process, $\mathrm{ZnO}$ nanospheres were suspended in ethanol and subsequently deposited on the glazed porcelain stoneware by a spray-coating technique to obtain ceramic glazes with active $\mathrm{ZnO}$ nanoparticles on the surface. The optimal layers were processed at $650^{\circ} \mathrm{C}$ and with $1 \mathrm{mg} / \mathrm{cm}^{2}$ of $\mathrm{ZnO}$ nanoparticles, which showed the fastest $\mathrm{Rz}$ ink transformation rate and thus superior photocatalytic performance. The enhanced activity was attributed to the good dispersion of $\mathrm{ZnO}$ nanoparticles on the layer formed on the surface of the glazed tiles. Furthermore, increasing the temperature of the thermal treatment $\left(700\right.$ and $\left.800^{\circ} \mathrm{C}\right)$ led to an increase in the size of the $\mathrm{ZnO}$ nanoparticles due to coalescence, which resulted in a decrease in the photocatalytic activity. This study deepens the understanding of the effect of the processing conditions on the photocatalytic activity of $\mathrm{ZnO}$-coated photoactive ceramic materials and provides a new avenue for their fabrication.

\section{ACKNOWLEDGMENTS}

H. R. Guzmán-Carrillo thanks CONACyT (National Council for Science and Technology) for financial support. The authors thank Mrs. P. Díaz, Mrs. E. Sánchez, and Mrs. María Grande from IETcc-CSIC for their technical assistance.

\section{AUTHOR CONTRIBUTIONS:}

Conceptualization: H.R. Guzmán-Carrillo, M. Romero-Perez, M. Castellote ; Data curation: H.R. Guzmán-Carrillo, E.Jimenez-Relinque ; Methodology: H.R. Guzmán-Carrillo, M. Romero-Perez; Resources: A. Manzano-Ramírez ; Roles/Writing, original draft: H.R. Guzmán-Carrillo, E.Jimenez-Relinque, A. Manzano-Ramírez; Writing, review \& editing: E. Jimenez-Relinque, M. Castellote, M. Romero-Perez.

\section{REFERENCES}

1. Berto, A.M. (2007) Ceramic tiles: Above and beyond traditional applications. J. Eur. Ceram. Soc. 27, 1607-1613. https://doi.org/10.1016/j.jeurceramsoc.2006.04.146.

2. da Silva, A.L.; Dondi, M.; Raimondo, M.; Hotza, D. (2018) Photocatalytic ceramic tiles: Challenges and technological solutions. J. Eur. Ceram. Soc. 38, 1002-1017. https://doi.org/10.1016/j.jeurceramsoc.2017.11.039.

3. Jiménez-Relinque, E.; Hingorani, R.; Rubiano, F.; Grande, M.; Castillo, Á.; Castellote, M. (2019) In situ evaluation of the NOx removal efficiency of photocatalytic pavements: statistical analysis of the relevance of exposure time and environmental variables. Environ. Sci. Pollut. Res. 26, 36088-36095. https://doi.org/10.1007/s11356-019-04322-y.

4. Jimenez-Relinque, E.; Castellote, M. (2014) Influence of the inlet air in efficiency of photocatalytic devices for mineralization of VOCs in air-conditioning installations. Environ. Sci. Pollut. Res. 21, 11198-11207. https://doi. org/10.1007/s11356-014-2632-2.

5. Takeuchi, M.; Sakamoto, K.; Martra, G.; Coluccia, S.; Anpo, M. (2005) Mechanism of photoinduced superhydrophilicity on the $\mathrm{TiO} 2$ photocatalyst surface. J. Phys. Chem. B. 109 , 15422-15428. https://doi.org/10.1021/jp058075i. 
6. Watanabe, T.; Nakajima, A.; Wang, R.; Minabe, M.; Koizumi, S.; Fujishima, A.; Hashimoto, K. (1999) Photocatalytic activity and photoinduced hydrophilicity of titanium dioxide coated glass. Thin Solid Films. 351, 260-263. https://doi. org/10.1016/S0040-6090(99)00205-9.

7. Jimenez-Relinque, E.; Sapiña, M.; Nevshupa, R.; Roman, E.; Castellote, M. (2016) Photocatalytic decomposition of pollen allergenic extracts of Cupressus arizonica and Platanus hybrida. Chem. Eng. J. 286, 560-570. https://doi. org/10.1016/j.cej.2015.10.106.

8. Reddy, P.V.L.; Kavitha, B.; Reddy, P.A.K.; Kim, K-H. (2017) TiO2-based photocatalytic disinfection of microbes in aqueous media: a review. Environ. Res. 154, 296-303. https:// doi.org/10.1016/j.envres.2017.01.018.

9. Vohra, A.; Goswami, D.; Deshpande, D.; Block, S. (2006) Enhanced photocatalytic disinfection of indoor air. Appl. Catal. B. 64, 57-65. https://doi.org/10.1016/j. apcatb.2005.10.025.

10. Jimenez-Relinque, E.; Rodriguez-Garcia, J.; Castillo, A.; Castellote, M. (2015) Characteristics and efficiency of photocatalytic cementitious materials: Type of binder, roughness and microstructure. Cem. Concr. Res. 71, 124-131. https://doi.org/10.1016/j.cemconres.2015.02.003.

11. Banerjee, S.; Dionysiou, D.D.; Pillai, S.C. (2015) Selfcleaning applications of TiO2 by photo-induced hydrophilicity and photocatalysis. Appl. Catal. B. 176, 396-428. https://doi.org/10.1016/j.apcatb.2015.03.058.

12. Jimenez-Relinque, E.; Castellote, M. (2018) Hydroxyl radical and free and shallowly trapped electron generation andelectron/ hole recombination rates in $\mathrm{TiO}_{2}$ photocatalysis using different combinations of anatase and rutile. Appl. Catal. A. 565, 20-25. https://doi.org/10.1016/j.apcata.2018.07.045

13. Fujishima, A.; Hashimoto, K.; Watanabe, T. (1999) TiO Photocatalysis: Fundamentals and Application, 1st ed., Tokyo Bkc, (1999).

14. Serpone, N.; Pelizzetti, E. (1989) Photocatalysis: fundamentals and applications, Wiley, New York, (1989).

15. Meseguer, S.; Galindo, F.; Sorlí, S.; Cargori, C.; Tena, M.; Monrós, G. (2006) Vidriados cerámicos con actividad fotoquímica: aplicación potencial a depuración ambiental. Cerámica Información. 333, 61-68

16. Bianchi, C.L.; Sacchi, B.; Capelli, S.; Pirola, C.; Cerrato, G.; Morandi, S.; Capucci, V. (2018) Micro-sized $\mathrm{TiO}_{2}$ as photoactive catalyst coated on industrial porcelain grès tiles to photodegrade drugs in water. Environ. Sci. Pollut. Res. 25, 20348-20353. https://doi.org/10.1007/s11356-017-9066-6.

17. Tobaldi, D.; Graziani, L.; Seabra, M.; Hennetier, L.; Ferreira, P.; Quagliarini, E.; Labrincha, J. (2017) Functionalised exposed building materials: Self-cleaning, photocatalytic and biofouling abilities. Ceram. Int. 43, 10316-10325. https://doi. org/10.1016/j.ceramint.2017.05.061.

18. Ducman, V.; Petrovič, V.; Škapin, S.D. (2013) Photo-catalytic efficiency of laboratory made and commercially available ceramic building products. Ceram. Int. 39, 2981-2987. https://doi.org/10.1016/j.ceramint.2012.09.075.

19. Bianchi, C.L.; Colombo, E.; Gatto, S.; Stucchi, M.; Cerrato, G.; Morandi, S.; Capucci, V. (2014) Photocatalytic degradation of dyes in water with micro-sized $\mathrm{TiO}_{2}$ as powder or coated on porcelain-grès tiles. J. Photochem. Photobiol. A. 280, 27-31. https://doi.org/10.1016/j.jphotochem.2014.02.002.

20. Rego, E.; Marto, J.; São Marcos, P.; Labrincha, J. (2009) Decolouration of Orange II solutions by $\mathrm{TiO}_{2}$ and $\mathrm{ZnO}$ active layers screen-printed on ceramic tiles under sunlight irradiation. Appl. Catal. A. 355, 109-114. https://doi.org/10.1016/j.apcata.2008.12.005.

21. São Marcos, P.; Marto, J.; Trindade, T.; Labrincha, J. (2008) Screen-printing of $\mathrm{TiO}_{2}$ photocatalytic layers on glazed ceramic tiles. J. Photochem. Photobiol. A. 197, 125-131. https://doi.org/10.1016/j.jphotochem.2007.12.017.

22. Vaiano, V.; Sarno, G.; Sannino, D.; Ciambelli, P. (2015) Photocatalyticproperties of TiO 2 -functionalized tiles:influence of ceramic substrate. Res. Chem. Intermed. 41, 7995-8007. https://doi.org/10.1007/s11164-014-1872-6.

23. Kuisma, R.; Fröberg, L.; Kymäläinen, H.-R.; PesonenLeinonen, E.; Piispanen, M.; Melamies, P.; Hautala, M.; Sjöberg, A.-M.; Hupa, L. (2007) Microstructure and cleanability of uncoated and fluoropolymer, zirconia and titania coated ceramic glazed surfaces. J. Eur. Ceram. Soc. 27, 101108. https://doi.org/10.1016/j.jeurceramsoc.2006.02.035.

24. Määttä, J.; Piispanen, M.; Kymäläinen, H-R.; Uusi-Rauva, A.; Hurme, K-R.; Areva, S.; Sjöberg, A-M.; Hupa, L. (2007) Effects of UV-radiation on the cleanability of titanium dioxidecoated glazed ceramic tiles. J. Eur. Ceram. Soc. 27, 4569-4574. $\mathrm{https://doi.org/10.1016/j.jeurceramsoc.2007.03.026.}$

25. Zhao, H.; Peng, C.; Wu, M.; Lv, M.; Wu, J. (2019) A crystallization method for preparation of anatase-based glass-ceramic glaze J. Eur. Ceram. Soc. 39, 1725-1729. https://doi.org/10.1016/j.jeurceramsoc.2018.11.027.

26. Tezza, V.B.; Scarpato, M.; Oliveira, L.F.S.; Bernardin, A.M. (2015) Effect of firing temperature on the photocatalytic activity of anatase ceramic glazes. Powder Technol. 276, 6065. https://doi.org/10.1016/j.powtec.2015.01.076.

27. Barmeh, A.; Nilforoushan, M.R.; Otroj, S. (2018) Wetting and photocatalytic properties of $\mathrm{Ni}$-doped $\mathrm{TiO}_{2}$ coating on glazed ceramic tiles undervisiblelight. Thin Solid Films. 666, 137-142. https://doi.org/10.1016/j.tsf.2018.09.007.

28. Onna, D.; Fuentes, K.M.; Spedalieri, C.; Perullini, M.; Marchi, M.C.; Alvarez, F.; Candal, R.J.; Bilmes, S.A. (2018) Wettability, photoactivity, and antimicrobial activity of glazed ceramic tiles coated with titania films containing tungsten. ACS Omega. 3, 17629-17636. https://doi.org/10.1021/acsomega.8b03339.

29. da Silva, A.L.; Dondi, M.; Hotza, D. (2017) Selfcleaning ceramic tiles coated with $\mathrm{Nb}_{2} \mathrm{O}_{5}$-doped$\mathrm{TiO}_{2}$ nanoparticles. Ceram. Int. 43, 11986-11991. https://doi.org/10.1016/j.ceramint.2017.06.049.

30. da Silva, A.L.; Muche, D.N.; Dey, S.; Hotza, D.; Castro, R.H. (2016) Photocatalytic Nb2O5-doped TiO2 nanoparticles for glazed ceramic tiles. Ceram. Int. 42, 5113-5122. https://doi.org/10.1016/j.ceramint.2015.12.029.

31. Gurbuz, M.; Atay, B.; Dogan, A. (2015) Synthesis of HighTemperature-Stable TiO2 anditsApplication onAg+-Activated Ceramic Tile. Int. J. Appl. Ceram. Technol. 12, 426-436. https://doi.org/10.1111/ijac.12165.

32. Zeng, Z.; Peng, C.; Hong, Y.; Lu, Y.; Wu, J. (2010) Fabrication of a Photocatalytic Ceramic by Doping Si$\mathrm{P}-$, and Zr-Modified TiO2 Nanopowders in Glaze. J. Am. Ceram. Soc. 93, 2948-2951. https://doi.org/10.1111/j.15512916.2010.03910.x.

33. Shakeri, A.; Yip, D.; Badv, M.; Imani, S.M.; Sanjari, M.; Didar, T.F. (2018) Self-cleaning ceramic tiles produced via stable coating of $\mathrm{TiO}$ nanoparticles. Materials. 11, 1003. https://doi.org/10.3390/ma11061003.

34. Taurino, R.; Barbieri, L.; Bondioli, F. (2016) Surface properties of new green building material after $\mathrm{TiO}_{\text {- }}$ $\mathrm{SiO}$ coatings deposition. Ceram. Int. 42, 4866-4874. https://doi.org/10.1016/j.ceramint.2015.12.002.

35. Sciancalepore, C.; Bondioli, F. (2015) Durability of $\mathrm{SiO}_{2}-\mathrm{TiO}_{2}$ photocatalytic coatings on ceramic tiles. Int. J. Appl. Ceram. Technol. 12, 679-684. https://doi.org/10.1111/ijac.12240.

36. Zhang, P.; Tian, J.; Xu, R.; Ma, G. (2013) Hydrophilicity, photocatalytic activity and stability of tetraethyl orthosilicate modified $\mathrm{TiO}_{2}$ film on glazed ceramic surface. Appl. Surf. Sci. 266, 141-147. https://doi.org/10.1016/j.apsusc.2012.11.117.

37. Qi, K.; Cheng, B.; Yu, J.; Ho, W. (2017) Review on the improvement of the photocatalytic and antibacterial activities of $\mathrm{ZnO}$. J. Alloys Compd. 727, 792-820. https://doi.org/10.1016/j.jallcom.2017.08.142.

38. Hariharan, C. (2006) Photocatalytic degradation of organic contaminants in water by $\mathrm{ZnO}$ nanoparticles: Revisited. Appl Catal A. 304, 55-61. https://doi.org/10.1016/j. apcata.2006.02.020.

39. Alcaraz, L.; Jiménez-Relinque, E.; Plaza, L.; GarcíaDíaz, I.; Castellote, M.; López, F.A. (2020) Photocatalytic Activity of ZnxMn3-xO Oxides and $\mathrm{ZnO}$ Prepared From Spent Alkaline Batteries. Front. Chem. 8, 661. https://doi.org/10.3389/fchem.2020.00661.

40. Strunk, J.; Kähler, K.; Xia, X.; Muhler, M.J.S.S. (2009) The surface chemistry of $\mathrm{ZnO}$ nanoparticles applied as heterogeneous catalysts in methanol synthesis. Surface science. 603, 1776-1783. https://doi.org/10.1016/j. susc.2008.09.063. 
41. Di Mauro, A.; Fragala, M.E.; Privitera, V.; Impellizzeri, G. (2017) ZnO for application in photocatalysis: from thin films to nanostructures. Mater. Sci. Semicond. Process. 69, 44-51. https://doi.org/10.1016/j.mssp.2017.03.029.

42. Ong, C.B.; Ng, L.Y.; Mohammad, A.W. (2018) A review of $\mathrm{ZnO}$ nanoparticles as solar photocatalysts: synthesis, mechanisms and applications. Renew. Sustain. Ener. Rev. 81, 536-551. https://doi.org/10.1016/j.rser.2017.08.020.

43. Kaushik, M.; Niranjan, R.; Thangam, R.; Madhan, B.; Pandiyarasan, V.; Ramachandran, C.; Oh, D-H.; Venkatasubbu, G.D. (2019) Investigations on the antimicrobial activity and wound healing potential of $\mathrm{ZnO}$ nanoparticles. Appl. Surf. Sci. 479, 1169-1177. https://doi.org/10.1016/j.apsusc.2019.02.189.

44. Saravanan, R.; Gupta, V.K.; Narayanan, V.; Stephen, A. (2013) Comparative study on photocatalytic activity of $\mathrm{ZnO}$ prepared by different methods. J. Mol. Liq. 181, 133-141. https://doi.org/10.1016/j.molliq.2013.02.023.

45. Marto, J.; São Marcos, P.; Trindade, T.; Labrincha, J. (2009) Photocatalytic decolouration of Orange II by $\mathrm{ZnO}$ active layers screen-printed on ceramic tiles. J. Hazard. Mater. 163, 36-42. https://doi.org/10.1016/j.jhazmat.2008.06.056.

46. Singh, G.; Kumar, S.; Singh, V.; Vaish, R. (2019) Transparent $\mathrm{ZnO}$ crystallized glass ceramics for photocatalytic and antibacterial applications. J. Appl. Phys. 125, 175102. https://doi.org/10.1063/1.5081988.

47. Mohsin, M.; Bhatti, I.A.; Ashar, A.; Mahmood, A.; ul Hassan, Q.; Iqbal, M. (2020) Fe/ZnO@ ceramic fabrication for the enhanced photocatalytic performance under solar light irradiation for dye degradation. J. Mater. Res. Technol. 9, 4218-4229. https://doi.org/10.1016/j.jmrt.2020.02.048.

48. Pascariu, P.; Homocianu, M.; Cojocaru, C.; Samoila, P.; Airinei, A.; Suchea, M. (2019) Preparation of La doped $\mathrm{ZnO}$ ceramic nanostructures by electrospinningcalcination method: Effect of $\mathrm{La}^{3+}$ doping on optical and photocatalytic properties. Appl. Surf. Sci. 476, 16-27. https://doi.org/10.1016/j.apsusc.2019.01.077.

49. Bouras, D.; Mecif, A.; Barillé, R.; Harabi, A.; Rasheed, M.; Mahdjoub, A.; Zaabat, M. (2018) Cu:ZnO deposited on porous ceramic substrates by a simple thermal method for photocatalytic application. Ceram. Int. 44, 21546-21555. https://doi.org/10.1016/j.ceramint.2018.08.218.

50. Romero, M.; Pérez, J. (2015) Relation between the microstructure and technological properties of porcelain stoneware. A review. Mater. Construcc. 65, e065. https://doi.org/10.3989/mc.2015.05915.

51. Guzmán-Carrillo, H.; Rivera-Muñoz, E.; CayetanoCastro, N.; Herrera-Basurto, R.; Barquera-Bibiano, Z.; Mercader-Trejo, F.; Manzano-Ramírez, A. (2017) Facile control of $\mathrm{ZnO}$ nanostructures by varying molar concentration of zinc acetate. Mater. Res. Bull. 90, 138-144. https://doi.org/10.1016/j.materresbull.2017.02.034.

52. Mills, A.; Hepburn, J.; Hazafy, D.; O’Rourke, C.; Krysa, J.; Baudys, M.; Zlamal, M.; Bartkova, H.; Hill, C.E.; Winn, K.R.; Simonsen, M.E.; Søgaard, E.G.; Pillai, S.C.; Leyland, N.S.; Fagan, R.; Neumann, F.; Lampe, C.; Graumann, T. (2013) A simple, inexpensive method for the rapid testing of the photocatalytic activity of selfcleaning surfaces. J. Photochem. Photobiol. A. 272, 18-20. https://doi.org/10.1016/j.jphotochem.2013.08.004.

53. Jimenez-Relinque, E.; Castellote, M. (2019) Rapid assessment of the photocatalytic activity in construction materials: Pros and cons of reductive inks and oxidative fluorescence probes versus standardized NOx testing. Catal. Today. 358, 164-171. https://doi.org/10.1016/j.cattod.2019.07.043.

54. Zita, J.; Krýsa, J.; Mills, A. (2009) Correlation of oxidative and reductive dye bleaching on $\mathrm{TiO} 2$ photocatalyst films. J. Photochem. Photobiol. A. 203, 119-124. https://doi.org/10.1016/j.jphotochem.2008.12.029.

55. Mills, A.; Wells, N.; O'Rourke, C. (2017) Probing the activities of UV and visible-light absorbing photocatalyst powders using a resazurin-based photocatalyst activity indicator ink (Rz Paii). J. Photochem. Photobiol. A. 338, 123-133. https://doi.org/10.1016/j.jphotochem.2017.01.030.

56. Mills, A.; Wells, N.; O'Rourke, C. (2014) Correlation between $\triangle \mathrm{Abs}, \triangle \mathrm{RGB}$ (red) and stearic acid destruction rates using commercial self-cleaning glass as the photocatalyst. Catal. Today. 230, 245-249. https://doi.org/10.1016/j. cattod.2013.11.023.

57. Jimenez-Relinque, E.; Castellote, M. (2019) Quick assessment of the photocatalytic activity of $\mathrm{TiO}_{2}$ construction materials by nitroblue tetrazolium (NBT) ink. Constr. Build. Mater. 214, 1-8. https://doi.org/10.1016/j.conbuildmat.2019.04.104.

58. Ehrt, D.; Flügel, S. (2011) Properties of zinc silicate glasses and melts. J. Mater. Sci. Eng. A. 1, 312.

59. Calas, G.; Cormier, L.; Galoisy, L.; Jollivet, P. (2002) Structure-property relationships in multicomponent oxide glasses. C. R. Chim. 5, 831-843. https://doi.org/10.1016/S1631-0748(02)01459-5 